\title{
THE
}

\section{ACRL New England Serials and Electronic Resources Interest Group Summer Program: Current Trends in E-Journals}

Andrée J. Rathemacher

University of Rhode Island, andree@uri.edu

Follow this and additional works at: https://digitalcommons.uri.edu/lib_ts_pubs

Part of the Library and Information Science Commons

\section{Citation/Publisher Attribution}

Rathemacher, Andrée J.. "ACRL New England Serials and Electronic Resources Interest Group Summer Program: Current Trends in E-Journals." , (2011). doi: 10.1016/j.serrev.2011.12.017.

This Article is brought to you for free and open access by the Technical Services at DigitalCommons@URI. It has been accepted for inclusion in Technical Services Department Faculty Publications by an authorized administrator of DigitalCommons@URI. For more information, please contact digitalcommons-group@uri.edu. 


\title{
ACRL New England Serials and Electronic Resources Interest Group Summer Program: Current Trends in E-Journals
}

Andrée J. Rathemacher

\begin{abstract}
This report covers a workshop held by the Serials and Electronic Resources Interest Group (SERIG) of the Association of College and Research Libraries New England Chapter, an independent chapter of ACRL. The program titled "Current Trends in E-Journals," was held on Thursday, August 18, 2011 at the Massachusetts College of Pharmacy and Health Sciences in Boston.
\end{abstract}

\section{E-Journals: The Vendor and Publisher Perspective}

The first speaker of the morning, Lois Bacon (director, Publisher Services, EBSCO Information Services), examined current trends in e-journals from the vendor and publisher perspectives. She was able to draw on her experience as EBSCO's liaison to publishers in the mid-western United States and to small and mid-sized publishers around the world. She stated that the financial downturn has had a massive impact on libraries and by extension, on publishers and vendors. All of these organizations have been forced to critically examine their missions, goals, and how they provide services. 
Bacon presented the results of EBSCO's latest annual surveys of libraries and publishers. The respondents to the surveys were among the larger customers and publishers of the 50,000 libraries and 83,000 publishers that EBSCO works with worldwide. The majority of the libraries responding were academic. According to EBSCO's survey data, the primary way that librarians have dealt with the new budget realities has been to drop print in favor of online-only subscriptions. The reporting of this data came as no surprise, as almost 70 percent of EBSCO's business is now for subscriptions with an electronic component (either online only or online plus print) and online-only subscriptions comprise almost 60 percent of EBSCO's sales. Publishers have found this transition difficult as they were used to two revenue streams, one from the electronic and one from the print. Even if print subscriptions were deeply discounted, they created a second stream of income. EBSCO's survey also asked librarians how they made the decision to keep or cancel a subscription. The most significant decision factor was usage statistics followed to a lesser degree by faculty recommendations, historical price increases, value metrics, and local rankings.

Librarians were asked in what parts of their budget they planned to increase expenditures. The five most popular responses involved e-content in one form or another: individual e-books, electronic journal subscriptions, e-book packages, e-journal packages, and full-text databases. Only a very small percentage of respondents indicated that expenditures on print materials would increase. For this reason, when small publishers call Bacon for advice and indicate that they are 
planning on publishing a new journal in print format, she explains to them that this strategy will not be successful and that they must offer materials online.

The vast majority of respondents to EBSCO's annual survey of publishers were STM and society publishers. Of the publishers responding to the survey, 49 percent indicated that the economic downturn has had a negative impact on their overall business, and 62 percent indicated that the downturn has changed their business practices. In many cases, publishers have not been replacing staff, have realigned staff, or have instituted hiring freezes. They are seeking operational efficiencies and are making cost-cutting moves, for example, by outsourcing distribution, hosting, and sales functions. Most publishers reported declines in their print business with 30 percent experiencing declines of greater than 10 percent. Bacon explained that publishers are still maintaining print because librarians are concerned about archiving and perpetual access. However, given the decline in demand for print, continuing to provide this format is no longer cost-effective. As a result, some publishers are issuing one year-end print volume in order to limit print runs to once per year, while others are formatting print journals in landscape format with two pages of text on each side of the printed page. Publishers are also experimenting with producing print issues on demand.

Publishers are struggling to find ways to recapture lost business and increase revenue. According to EBSCO's survey, publishers are attempting to do this by starting new titles (54 percent), creating subject oriented packages of e-journals (51 percent), increasing the size of ejournal packages (40.8 percent), acquiring titles (32.7 percent), and eliminating titles (24.5 
percent). Bacon mentioned other publisher strategies, including increasing advertising and marketing activities, adding e-book content, enhancing content, and offering new delivery methods. To add new titles, publishers are often acquiring other publishers; for example, in recent years Taylor and Francis bought Haworth Press, Laurence Erlbaum, and a number of other smaller publishers. Evidence of this consolidation in the industry can be seen by the fact that in 1994, the ten largest publishers accounted for 19 percent of EBCSO's revenue, while in fiscal year 2011 they accounted for 62 percent. Libraries are now receiving content from far fewer publishers than in the past.

In this context, smaller publishers are concerned with maintaining their subscriber bases and with increasing their total numbers of subscribers. The JSTOR Current Scholarship Program provides one example of this strategy. In this new model, publishers are able to reduce costs and potentially grow their subscriber bases and revenues by centralizing subscription fulfillment and e-content delivery services through JSTOR. Bacon is often asked to advise smaller publishers seeking to offer online subscriptions. She tells them that they need to find a host that will allow them to provide IP-verification. She explains that if they provide access solely via username and password, as many want to do, that they will lose subscribers and will never get them backonce libraries spend their subscription money on something else, it is gone forever.

EBSCO's publisher survey also asked publishers about their planned pricing activities. Eightysix percent of publishers surveyed planned to increase prices. Bacon explained that in the online environment publishers face higher costs, which include hosting services, increased bandwidth to 
accommodate the growing use of streaming video, and programmers to meet growing user expectations for mobile applications and other new services. Over 50 percent of publishers plan on changing pricing models, for example a change to tiered pricing. Bacon advises publishers to think carefully about this strategy and to use common sense. She encourages publishers to use Carnegie classifications as tiers, because this is an objective, consistent standard, though Carnegie classifications do not apply to subscribers outside of the United States. Publishers need to be sensible about tiers; if the difference between tiers is only a few dollars, the increased revenue will not be worth the cost of changing their fulfillment systems to accommodate tiers. Bacon also points out to publishers that raising prices brings their journals to the attention of librarians, who might decide to cancel them. Bacon noted that two years ago many publishers responded to requests from librarians to keep 2010 prices the same as 2009 prices. Oddly, these publishers actually experienced a greater number of cancelations than publishers who raised prices. Bacon believes that this happened because the publishers who kept prices steady advertised this fact, bringing attention to their journals and causing librarians to evaluate whether the subscriptions were needed at all.

EBSCO asked publishers what their views were of the future of "big deal" journal packages. Opinion was fairly evenly split, with 40.4 percent unsure of the future of big deal packages, 31.9 percent believing that big deals are secure, and 27.7 percent thinking that big deal packages will be unbundled. Bacon believes that this is an area in which the opinions of publishers and those of librarians do not match up. Librarians have been expressing a strong desire to break up big deal packages or to renegotiate three-year big deal contracts. 
A promising alternative to the big deal is patron driven acquisition of journals—that is, allowing patrons to access journal articles on a pay-per-view basis. Bacon noted that purchasing articles on demand reduces costs for libraries and expands access for their patrons to a greater number of titles. Cost-per-use for on-demand articles is dramatically less than cost-per-use of seldom-used subscriptions, and the availability of usage statistics allows for the identification of heavily requested on-demand titles as potential new subscriptions. In addition, by relying on pay-perview access to articles, libraries can avoid the storage costs associated with print journals. Publishers gain by having a greater number of their titles exposed to readers and libraries than would be the case in the subscription model, potentially leading to increased sales. In order for ordering articles on demand to be a viable alternative to the big deal for libraries, librarians need to monitor usage to make sure that the cost of delivering articles does not exceed the cost of the big deal subscription packages that document delivery replaces. A patron-driven strategy also makes budgeting difficult, as libraries do not know ahead of time how much they will spend purchasing articles on demand.

Bacon continued by summing up publishers' views of the future. Publishers want to increase the usage and discoverability of their content. To this end, they are including more of their content in full-text databases to increase exposure to non-subscribers. They are also encouraging activation of online subscriptions given that up to 30 percent of online subscribers do not turn on access to subscribed content. They are enhancing journal content by adding video, data sets, CME (continuing medical education) tests for medical professionals, and even holograms. 
Journal publishers and aggregators are offering more e-books and are integrating e-book content into journal search results. Publishers are looking to deliver content in different ways, for example on mobile devices.

Bacon highlighted the benefits to both publishers and libraries of working with subscription agents. For libraries, subscription agents provide top level customer service for electronic content purchases. EBSCO Information Services has changed its focus away from print to supporting the acquisition and management of online journals. For publishers, EBSCO provides consulting services through their Publisher Relations Team. EBSCO's PubLinx system, the equivalent of EBSCONET for publishers, allows publishers to view data and reports on their own publications as well as subscriber information. In addition, EBSCO Publishing is a leading supplier of e-content and offers multiple tools for making publisher content discoverable and accessible.

Bacon concluded by summing up the key trends in e-journals. Both libraries and publishers are seeking to reduce costs while maintaining services. Libraries are transitioning from print to online-only resources, often skipping the intermediate print-plus-online step. Big deal and other publisher packages of online journal content are at a crossroads; libraries and publishers have very different views of the value of these packages in the future. Publishers are looking to reduce costs internally while increasing revenue through enhanced content and discoverability. Both publishers and librarians agree that increasing usage is essential. 


\section{Alternatives to Subscriptions: Trial and Error at Wellesley College}

Deborah Lenares (manager of acquisitions and resource sharing, Wellesley College) was the second speaker of the morning. She discussed her attempts at Wellesley College to seek alternatives to subscriptions through using interlibrary loan, full-text database access, and payper-view article access. Lenares emphasized that these alternatives, which have worked well at Wellesley College, might not be appropriate for every institution. Wellesley College is a small, highly selective, liberal arts women's college with 2300 students. They can experiment with alternatives to subscriptions in ways that might not be possible for schools with larger student populations, graduate programs or relatively smaller budgets.

Lenares explained that the subscriptions she targets for cancelation, and for which she seeks alternatives, are all low-priority titles based on use and/or cost-per-use and that a subscription is always preferable for heavily used journals. She emphasized that since her analysis of subscriptions is based on usage data, she has converted as many subscriptions as possible from print to online-only so that such data are available, even if the price of an online subscription is significantly higher than the print. Wellesley uses Serials Solutions' 360 Counter product for compiling usage data, which are sorted by lowest use and highest cost per use and examined annually to identify subscriptions for review. Wellesley consults three years of usage data and targets titles with fewer than five articles viewed per year or with a cost per use above $\$ 100$. They do not look at other criteria such as ISI impact factors or Eigenfactor scores, because they care only how the journal is used at Wellesley, not anywhere else. The list of potential titles to 
be canceled is distributed to the faculty for comment, and the list includes the way in which content from each title will continue to be available post-cancelation.

One of the ways in which Wellesley continues to provide library users with access to canceled, low-use subscriptions is through interlibrary loan. By using RapidILL from Colorado State, they have achieved an average turnaround time of fourteen hours and can fill 91 percent of requests. Lenares noted that CONTU guidelines limit borrowing to five recent articles per title per calendar year; after the fifth, copyright fees must be paid to the publisher through the Copyright Clearance Center. Despite the fast turnaround time and high fill rate for articles requested through interlibrary loan, Wellesley faculty complain that relying on interlibrary loan disrupts their research cycle, as they cannot bounce from one citation to the next.

A second alternative to low-use subscriptions at Wellesley College is accessing articles from canceled journals through full-text databases. Lenares presented cautionary data by Thohira, Chambers and Sprague (2010) showing that full-text databases are unreliable if your community uses a journal title heavily (Thoria et al., 2010). In 2010, these authors found that the latest issue of a journal was available in full-text databases for only 56 percent of journal titles, though coverage (inclusion of all the articles in an issue) had improved since 2000, as had the quality and availability of graphics. Stability of journal titles in full-text databases was also an issue, with 34 percent of titles lost over ten years from the subset of databases studied. Lenares believes these data confirm that full-text databases are unreliable for titles used heavily by a community Such titles should not be canceled, but if a title is low use or has a high cost-per-use, 
access through full-text databases is an acceptable substitute to a subscription. If a title's full text is subsequently dropped from a library's collection of databases, a decision to reinstate the subscription can be made at that time.

Next, Lenares discussed Wellesley's experiment with providing library-administered, pay-perview articles through Wiley-Blackwell's Article Select service. In this model, the library makes an advance payment to the publisher for a certain number of articles or "tokens." As campus users download articles, the library's account is debited and must be replenished periodically. In 2009 and 2010, Wellesley canceled sixty-eight Wiley-Blackwell subscriptions totaling $\$ 100,000$. The canceled titles had costs-per-use of greater than $\$ 20$. Lenares used the money saved to purchase Article Select tokens at a cost of $\$ 10$ per token. As a result, Wellesley users can download articles from any non-subscribed Wiley-Blackwell journals after clicking through a confirmation screen. Lenares explained that it is not possible to choose which journals are available to patrons through Article Select; the Article Select tokens work for all WileyBlackwell titles, although access can be limited to frontfile or backfile titles. For this reason, Lenares chose to turn on access to all Wiley-Blackwell journals, not just to canceled titles, in Wellesley's Serials Solutions journal list and link resolver.

Lenares displayed a chart showing that Article Select use at Wellesley has risen steadily over the past two years. She attributes part of the increase to a change in wording on Wiley-Blackwell's confirmation screen. The screen used to alert the user that the library would pay a fee for the user to access the article, possibly causing users to carefully consider their request before 
proceeding, but it no longer does so. In 2010, Wellesley users spent $\$ 66,500$ of Article Select tokens, far less than the $\$ 100,000$ value of the canceled subscriptions. However, during the first six months of 2011, Article Select expenditures have already reached $\$ 42,000$, which suggests that at some point in the near future the library will be spending as much as, if not more than, the value of the original subscriptions canceled. Part of the increase in costs is the increased price of each token from $\$ 10$ to $\$ 11.50$. Despite these growing costs, Lenares believes that the pay-perview experiment has been successful as Wellesley users can now access articles from over 1800 Wiley-Blackwell journals. Further, much of the use of these titles is "long tail use," in that 45 percent of all articles downloaded are from journals accessed only once.

Lenares also experimented with pay-per-view article delivery through IngentaConnect. In 2009, Wellesley canceled thirty low use or high cost-per-use titles worth $\$ 100,000$ that were available through IngentaConnect. After paying a $\$ 6000$ platform fee, Wellesley placed $\$ 10,000$ in a deposit account. Administrative setup was extensive and time-consuming, with many options for customization. Articles requested through IngentaConnect were available in two ways, depending on the publisher, either through on-screen delivery or delivery by fax through Ariel. In March 2009, three months after Wellesley's service began, IngentaConect dropped the Ariel service. This resulted in the immediate unavailability of eleven of Wellesley's thirty-five selected titles. By October 2009, only $\$ 1000$ had been used from the deposit account. Lenares believes that library users were inhibited from ordering articles because they were alerted by IngentaConnect that the library would be charged $\$ 45$ for each article delivered. Wellesley canceled the service and requested a refund. 
Lenares mentioned another document delivery option that Wellesley has not yet implemented but is watching closely, Get It Now from the Copyright Clearance Center. This new service offers five-minute delivery via email, twenty-four hours a day, of articles requested directly by library users. The service can be integrated into the library's link resolver, and the library can control which journal titles are available for request as well as the number of requests allowed per patron in a given time period. Lenares intends for Wellesley to experiment with Get It Now later this year once the number of participating publishers has expanded. The price per article ranges from $\$ 25$ to $\$ 45$, which provides Wellesley with a new price point for cost-per-use analysis.

Lenares concluded with the recommendation that program attendees should be willing to take the risk of trying alternatives to subscriptions with the option of retreating if necessary. This requires flexibility, as the rules can change in the middle of the game, as well as a willingness to continually evaluate success.

\section{Trends in Licensing and Related Copyright: One Step Forward, Two Steps Back}

The third and final presenter in SERIG's program was Janet Belanger Morrow (head of resource management, Northeastern University), who discussed what she referred to as "unhappy" trends in licensing and copyright. The first of these trends is the growing prevalence of click-through end user licenses (EULs) for electronic resources, probably, she believes, because such licenses 
have become common in the downloadable e-book and e-reader marketplace. Morrow has started to see EULs referenced in the site licenses she negotiates on behalf of the Northeastern University Libraries. What she finds particularly worrisome is that the EULs initially contain the same language as the site license, but over time the EUL language can change, thus potentially negating some of the terms of the site license. If a site license references an EUL, Morrow recommends negotiating wording to be added to the site license stating that the language in the site license governs in the case of any discrepancy between the site license and the EUL. She also recommends adding a clause to the site license requiring the publisher to notify the library via e-mail when they update any terms of their EUL, though publishers often forget to do so. EULs seem to be less of a concern legally when they are clearly aimed at the end user, though users can be confused by conflicting information about how they can use content if they are confronted with both an EUL and the terms of their institution's site license as communicated through an electronic resource management system, for example. Morrow believes that publishers should know better than to require EULs when a site license is present, and that at Northeastern, they are not willing to do the work of negotiating two different licenses for the same content.

Another trend, according to Morrow, is the re-emergence in site licenses of language prohibiting the disclosure of pricing information and other terms of the agreement. These clauses had mostly disappeared from licenses before the Association of Research Libraries (ARL) released a statement in June 2009, asking members not to sign confidentiality or nondisclosure agreements (Association of Research Libraries). As a response to the reappearance of these terms, Cornell University Libraries issued a statement in March 201, declaring that they would "no longer sign 
contracts with publishers that include confidentiality agreements" and that "libraries should be able to talk to each other about the details of these contracts," especially in light of the current difficult budget climate (Cornell University Library). Since Cornell's statement, other libraries have taken a similar stance, including Dartmouth College, Brown University, Duke University, Emory University, Johns Hopkins University, Massachusetts Institute of Technology, New York University, and Columbia University. Morrow stated that Northeastern University has been successful in negotiating these statements out of license agreements, and she commends many of the larger publishers and society publishers that do not include them. Morrow questioned why publishers bother to include such statements; do they really think that librarians do not discuss license terms with one another? Besides price, there are few license terms that remain secret among libraries. She noted that public institutions have a stronger negotiating position as most state laws would negate any nondisclosure restrictions in a license. Morrow finds it ironic that these same licenses that prohibit disclosure of the terms of the license also contain notification requirements stipulating that librarians notify library users of the terms of use.

Another trend that Morrow identified is the emergence of extremely restrictive e-book licenses. She noted that librarians have been successfully licensing subscriptions to e-books for some time_Early English Books Online and Safari Books Online are two early examples—and that these licenses are similar to licenses for databases or e-journals. Lately, however, she has seen ebook licenses that contain restrictive language of the sort that was negotiated out of database and e-journal licenses years ago. These new licenses bring back language on jurisdiction and indemnification, for example, and do not contain language allowing interlibrary loan or fair use. Morrow believes the lack of provision for interlibrary loan is the biggest issue in e-book 
licensing. Technology to allow for inter-library lending of e-books has not been developed, and publishers are afraid of losing control of their content. They are suggesting solutions such as allowing short-term loans for which either the library or the end user must pay. Morrow believes that the likely solution to the interlibrary loan problem will be loans at the chapter level with the alternative being an unacceptable amount of digital rights management (DRM) restriction. The technology will need to catch up to our expectations. Meanwhile, Morrow advises that libraries push back against publishers to make sure that fair use and interlibrary loan provisions appear in e-book licenses.

An additional problem with current e-book licenses is that separate licenses are often required for e-books, journals, and reference works from the same publisher or vendor, even when the licenses are nearly identical. At Northeastern University, Morrow has been working hard to get publishers to use addendums to existing licenses instead of separate e-book licenses. Publishers often refuse, explaining that e-books are handled by a different division of the company, even though multiple licenses are bad practice for both publishers and libraries from a workflow point of view.

In the context of e-book licensing, Morrow mentioned services available for academic libraries from OverDrive, a company that provides e-book lending services primarily to public libraries. Northeastern is currently investigating OverDrive for offering e-book versions of testing manuals, travel guides, and language guides. The best part of the OverDrive service, according to Morrow, is that books can be downloaded to e-readers. There are no interlibrary loan rights 
for books offered through OverDrive, however, and DRM restrictions cause books to disappear from e-readers at the end of the lending period. What worries Morrow is whether OverDrive will allow library users outside of the United States to download e-books to a reader, which is important for students studying abroad or traveling and should ideally be added to the license. Morrow noted that OverDrive was the company that first announced the decision by publisher HarperCollins to delete e-books from library collections after they had been checked out twentysix times thus forcing libraries to purchase the book again, which drew an outcry from public librarians. Morrow is very worried that this is a policy that other commercial publishers will emulate; librarians need to make it clear to publishers that such terms are not acceptable.

Morrow next discussed developments with SERU, the Shared Electronic Resource Understanding, which was developed by NISO (National Information Standards Organization). SERU is a recommended practice written in vernacular language that can serve as an alternative to a license agreement. Its goal is to clearly communicate a shared understanding between publishers and libraries of the appropriate uses of e-resources and the expectations of both parties (SERU includes many of the same topics that license agreements typically cover and are now widely accepted). Publishers and libraries wishing to use SERU can save the time and effort involved in negotiating a license agreement; with SERU, purchasing terms are negotiated separately from the agreement on how the product will be delivered and used. On August 17, 2011, the SERU Standing Committee released for comment a draft revision of SERU that better accommodates e-books (Lamoureux). Morrow explained that the Committee tried to make SERU more generic, for example with replacing "subscriber" by "acquiring institution" and "publisher" by "provider." In reference to e-books, the draft revision adds the word "chapters," 
to the "Use of Materials" section to help address interlibrary loan and fair use, stating that "some of the accepted uses include ad hoc sharing of single articles and chapters by individuals for purposes of scholarship or private study and, for academic libraries, provision of content for classroom and courseware purposes."

Another recent development in licensing is the development of author rights model license language by an ad hoc working group organized by the Association of Research Libraries (Author Rights Model License Language). By negotiating with publishers to add language on author rights to license agreements, libraries could negate any limitations imposed by the publisher on the ability of institution-affiliated authors to deposit their work in an institutional or other open access repository. Since this language is so new, Morrow is not aware of any institution that has successfully incorporated it into a license negotiated with a publisher. She explained that she has mixed feelings about it. While this language is helpful in getting material into institutional repositories quickly, it also sets a potentially dangerous precedent whereby one contract, the license, negates a third party contract between author and publisher.

As a final trend, Morrow noted that there is trouble brewing between libraries and STM publishers over document delivery and interlibrary loan. In June 2011, the Association of Research Libraries released a task force report affirming libraries' right to participate in international interlibrary loan and document delivery activities (Association of Research Libraries, 2011). Morrow explained that the ARL Task Force on International Interlibrary Loan and Document Delivery Practices had been formed in response to language appearing in licenses 
that restricted libraries in the United States from making interlibrary loans to libraries in other countries. According to Morrow, this language had disappeared from license agreements for a number of years and recently started reappearing. Meanwhile on May 31, 2011, the International Association of Scientific, Technical \& Medical Publishers (STM) issued a statement that said, in part, that document delivery should be an exception and is best coordinated by rights holders. The statement also noted that cross-border document delivery by libraries should be governed by arrangements negotiated directly with publishers or their representatives and that "on-site print document delivery to non-commercial patrons is a good compromise (International Association of Scientific, Technical \& Medical Publishers)." In late June, the International Coalition of Library Consortia released a response to the STM statement contending that international interlibrary loan and document delivery is "adequately and appropriately governed by current copyright law (International Coalition of Library Consortia)." Morrow believes that this is a big issue for libraries offering programs in other countries as well as those who borrow and lend to libraries abroad. This language needs to be negotiated out of contracts with publishers.

Morrow concluded by summarizing the "steps back" and "steps forward" related to trends in licensing and copyright. Steps back include attacks on fair use, especially interlibrary loan rights; licenses that revert to unfavorable language that libraries negotiated out of agreements years ago; and the proliferation of separate license documents for different categories of resources from the same publisher. Steps forward include best practices documents, for example, SERU and model interlibrary loan and e-reserve policies that have been developed, and the ability of librarians to negotiate. Morrow urged attendees not to be afraid to change licenses, even click-through licenses, if they prohibit fair use. To help negate marginal language in 
licenses that librarians are unable to negotiate out, Morrow suggests pressing for the addition of the clause, "Nothing in this agreement is meant to restrict the Fair Use Rights of the Licensee under U.S. Copyright Law." Contracts and licenses are two-sided agreements, and both sides must be free to negotiate. Librarians should be prepared to walk away if necessary.

\section{References}

Thohira, Mariyam, Mary Beth Chambers, and Nancy Sprague, "Full-text databases: A case study revisited a decade later," Serials Review 36, no. 3 (September 2010): 152-160, http://dx.doi.org/10.1016/j.serrev.2010.07.001. (accessed August 22, 2011.)

Copyright Clearance Center, “Copyright clearance center launches 'Get It Now' for academic institutions," http://www.copyright.com/content/cc3/en/toolbar/aboutUs/newsRoom/pressReleases/press_2011 /press-release-11-04-11.html (accessed August 22, 2011.)

Association of Research Libraries, "ARL encourages members to refrain from signing nondisclosure or confidentiality clauses," http://www.arl.org/news/pr/nondisclosure5june09.shtml (accessed August 23, 2011). 
Cornell University Library, "Library calls for contract transparency and begins to reject nondisclosure clauses," http://news.library.cornell.edu/news/110323/nondisclosure (accessed August 23, 2011).

Selden Lamoureux, "Invitation to comment on SERU draft for ebooks," SERUINFO discussion list, http://www.niso.org/lists/seruinfo/archive/msg?list_name=seruinfo\&monthdir=201108\&msg=m sg00000.html (accessed August 23, 2011).

Author rights model license language, http://authorrights.wordpress.com/ (accessed August 23, 2011).

Association of Research Libraries, "Report of the task force on international interlibrary loan and document delivery practices," Research Library Issues, no. 275 (June 2011): 2-7, http://publications.arl.org/rli275/2 (accessed August 23, 2011).

International Association of Scientific, Technical \& Medical Publishers, "STM statement on document delivery," http://www.stm-assoc.org/industry-news/stm-statement-on-documentdelivery/ (accessed August 23, 2011). 
International Coalition of Library Consortia, "ICOLC response to the International Association of Scientific Technical and Medical Publishers (STM) Statement,"

http://www.library.yale.edu/consortia/2011-stm-ill.htm (accessed August 23, 2011).

\section{Contact info:}

\section{Andrée J. Rathemacher}

Head, Acquisitions

University Libraries, University of Rhode Island

15 Lippitt Road

Kingston, RI 02881-2011

Phone: (401) 874-5096

Fax: (401) 874-4588

E-mail: andree@uri.edu

http://www.uri.edu/library/ 